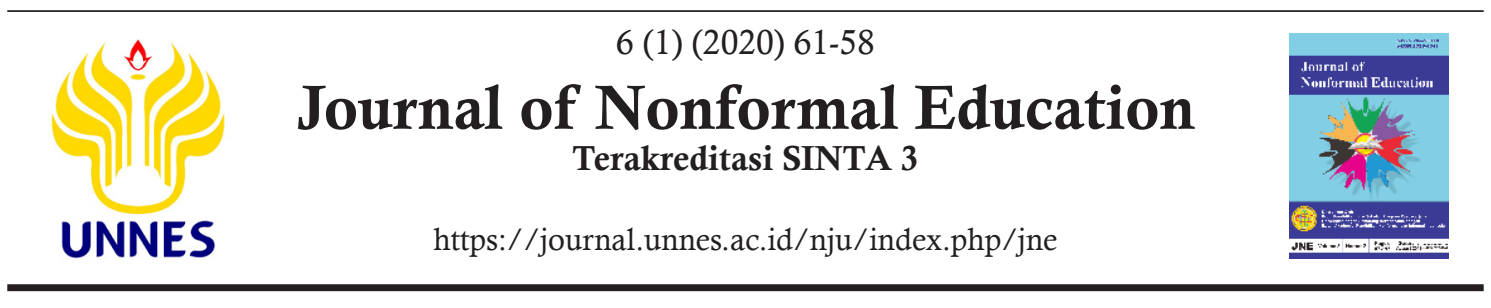

\title{
The Empowerment of Labour Women Picking Coffee Through the Education of Functional Literacy Based on Local Potentials
}

\author{
Deditiani Tri Indrianti ${ }^{\bowtie}$, Sri Hartatik, Linda Fajarwati
}

DOI: http://dx.doi.org/10.15294/jne.v6i1.21992

Universitas Jember, Indonesia

\section{History Article}

Submitted 21 November 2019 Revised 24 January 2020

Accepted 4 February 2020

\section{Keywords}

Education of functional literacy; Women picking coffee workers; Local potentials

\begin{abstract}
Women picking coffee workers have a big enough role in all lines. However, the level of education and knowledge is still relatively low. It occupies a subordinate and marginally positioned position. This research aims to find the empowerment of women's coffee picking labourers through the process of functional literacy programs. The existence of the program is expected to improve women's empowerment The study was designed with a qualitative approach. Researchers use two primary types of data (1) Primer, i.e. data obtained by researchers directly from speakers as informers who are directly related to the empowerment of the local potential coffee-picking labour. Primary data sources of research using interviewing techniques and observation techniques (2) secondary, are supplementary research data that will be obtained through reports in the form of learning activities, documents, and textbooks relevant to the purpose of research. Before processing, the collected primary data is checked for the validity of the data. In this case, it is used triangulation technique, to be processed and analyzed by the technique of Gender Analysis Pathway (GAP). Where the gender engineering pathway analysis is used to analyse the policy of development programs, in this case, is a functional literacy program. The results showed that there was an increase in the empowerment of female coffee picking labours through a functional literacy program based on local wisdom. Reading, writing and counting ability can realize women have an unworthy job. The re-formulation of the learning design conducted through functional literacy programmes became the main thing for working women picking coffee in recognizing local potentials designed in accordance with local characteristics. The design of attention-learning to local potentials has become a key thing in enhancing the power of women so that it can find the resources that are based in everyday life.
\end{abstract}




\section{INTRODUCTION}

Functional literacy programs are a form of non-formal education services and are aimed at communities who have not been able to get access to formal education services. every program that is implemented requires suitability between the needs of community life with the context of ecological life, both in biological potential, nonbiological life potential, even a system of tradition that lives and thrives in the communiaty (Ansori, 2018). The Program is oriented towards increased reading, writing, and counting capabilities that function to improve the life's standards by utilizing the potential surrounding it as a source of life (Pathak, et al., 2015). Where the education principle of functional literacy should be adjusted to the needs, interests and potential that exist around the citizens learn.

However, not all functional literacy programs are organized concerning local potentials. Educated women are one of the most valuable investments for a State in promoting sustainable development programs in increasing prosperity country (Karwati, et al., 2018). As in the village of Harjomulyo, district Silo which is the highestblind area in Jember Regency, and is dominated by women picking coffee workers. Where the reading ability, write count is still relatively low, as a result, women picking coffee unions occupy a subordinate position and are marginally in society. The role and position of women picking coffee workers have not impacted the quality of life improvement.

The gaps can be seen in various facets of life, this is due to the inequality of access, participation and control. Also, gender construction in the community still puts women in an unjust position. The disparity of gender injustices of female coffee picking workers is a humanitarian problem that must be dealt with seriously. Whereas the societal perspective can closely resemble the individualistic perspective in its views about inequality and gender differences, and executives often overlap the two ideologies in practice, the societal pathway theoretically corresponds with different change efforts, as detailed in later sections (Wynn, 2020).

These capabilities can be improved through a functional literacy program that is more oriented towards improved read, write, and count capabilities. To then be able to realize women picking coffee workers as a social planner characterized by the ability to search or find useful information in daily life (Pathak et al., 2015). In addition to the education of functional literacy is also an effort to build a transformative critical awareness in enhancing the empowerment of women (Latifa, 2015). The basic competencies provided in the functional literacy program not only focus on improving the basic ability to read, write and count alone, but more on improving in discovering and recognizing the existing potential in Its surroundings as well as being able to develop it as a source of survival.

Nevertheless, the local potential that can be utilized and developed in the education program of functional literacy has not been a focus of program attention, so the literacy program is still partial (Lestari, 2017). Considering, each region has characteristics that are specific to local. As the research has been conducted (Indrianti \& Khutobah, 2017), that local potentials that are around the citizens learn can be utilized and developed in the program of functional literacy. The research has resulted in the local potential of the study of cultural, social, and economic aspects that can be used as a learning resource. The existence of local potentials that have been initiated as a form of poverty alleviation strategy can role as a medium in forming a learning group and as a learning material so that it can improve the quality of life of women.

Starting from the above background, this article focuses on the efforts to identify the empowerment of women who do coffee quotes through the education of functional literacy based on local potentials. Hopefully, it can be the orientation of policymakers in doing the design of literacy programs that pay more attention to the characteristics of local Graduates who have more sensitivity in planning a better life to fit practical and strategic gender needs without the occurrence of cultural denial.

\section{METHODS}

The study was designed with a qualitative approach. The research location is determined by purposive area method focused in the village of Harj om Ulyo Silo District of Jember District, with the consideration that the location is the largest coffee producing area in Jember district and become a commodity Major export. However, female-dominated coffee managers have relatively low levels of empowerment. On the other hand, there is a local potential that has not been enabled and developed by women to improve the quality of life. Researchers use two primary types of data (1) Primer, i.e. data obtained by researchers directly from speakers as informers who are directly related to the empowerment of the local potential 
coffee-picking labour.

Primary data sources of research using interview techniques and observation techniques, where: (a) interview techniques are excavated through the informant consisting of the organizers of literacy programs, learning citizens and community leaders, as well as literacy program tutors Functional. In this case, the informant is expected to help provide information following the purpose of this research; (b) Observation techniques are used to observe the empowerment of the community and the potential of the local people who are in the area of the female coffee picking workers both at the household level, as well as society; (2) The secondary is a supplementary research data that will be obtained through a report in the form of learning activities, documents, or textbooks relevant to the purpose of research.

Before processing, the collected primary data is checked for the validity of the data. In this case, it is used triangulation technique, to be processed and analyzed by the technique of Gender Analysis Pathway (GAP). Where the gender engineering pathway analysis is used to analyse development program policies in this regard is a functional literacy program, consisting of five phases, among others: first, the stage of goal identification and the target program policy Functional literacy. Secondly, the stage presents the sorted data by gender as the opening date of the Eye-opener, in this case, the data is presented qualitatively. Third, the analysis stage of the source of occurrence or cause of gender gap is examined from the aspect of access, participation, control and benefits. Fourth, identify gender issues that occur in the functional literacy program. Fifth, gender-equitable policy formulation.

\section{RESULT AND DISCUSSION}

Local wisdom is the basis for policymaking at the local level in various areas of life such as; Health, agriculture, education, natural resource management and rural community activities (Darusman, 2016). Women picking coffee is still left behind, the social, economic and cultural conditions of the lame place women in subordinate positions. As a result, women picking coffee workers experienced illiteracy. Functional Literacy has the function of developing basic human capabilities that include the ability to read, write and count functional in improving the quality and standard of living the society (Laksono, et al., 2018). The illiterate rural people are left behind in the term of knowledge, skill, and men- tality against reformation and development (Arbarini, et al., 2018).

Therefore, the presence of functional literacy education aims to eradicate the illiteracy of the alphabet to improve literacy as well as embody the indispensable women picking coffee workers (Barton, 2017). Hopefully, it can have a knowledge of literacy and numeracy that works for life and oriented to the increasing standards of living better and more empowered. As (Lestari, 2017) that, the issue of illiterate is also related to the inability of the community in understanding, analyzing and solving the problems that surround the community in its life. Meanwhile, the understanding of society can be improved through literacy education to gain the ability to read alphabetically or to read words that impact the day.

One of the main basic women of coffeepicking labourers seeks to improve insight and knowledge is the ability to read, write and count or often be called "literacy". The literacy rate is a measure of the educational indicator to calculate the Human Development Index (HDI) (Harttgen \& Klasen, 2010). In the calculation of an educational indicator, the literacy rate (read: Calistung ability) weighs twice as much as the old average indicator of the school. Life skill education to facilitate instructors in managing learning following the principles of andragogy or approach to adult education that characterized the experience of citizen learning (Lestari, 2016).

Through this skill activities, the entrepreneurial interests of young men are resurrected, to be directed towards the development of economic efforts management. Skill training provided on life skills-oriented (Falaly, 2016). Where reading and writing skills are important to facilitate women's quotation labourers receive various renewals (Herwiandini, 2018). The ability to recieve a variety of information and knowledge is obtained from a program of functional literacy that is done consciously and can be planned. It also implicitly implies that the significance of a woman's identity as a worker is undermined when women hold the primary responsibility for child care (Zhou, 2017).

The main purpose of a functional literacy program does not only convey the characters. However, more on the increase of self-reliance delivered through the recognition of the script as a form of the female energy quotation of coffee. This condition is in line with the statement (Herwiandini, 2018) that, the main purpose of the Empowerment program is to form individuals and communities into independent, self-reliant in thinking, acting and controlling what is done. 
According to him, self-reliance is a condition experienced by the community and characterized by the ability to think, decide and do something that is deemed appropriate to achieve solving the problems faced with the use of power Ability to be sensitive to surrounding conditions. The statement was strengthened by (Asfi, 2015) that to be empowered, communities need to raise critical awareness, have the opportunity to make choices and the ability to act. Therefore, to realize the power of the female coffee picking labourer, it is possible to provide a wider stimulus and opportunity and improve the ability to recognize and manage local resources around it.

The success rate of the functional literacy program is more oriented towards improved letter and number recognition. The community's ability to meet the potential surrounding is not yet a major concern in measuring the success of the program (Harttgen \& Klasen, 2010). The presence of local potentials is utilized and developed in a functional literacy program. The tasks of National Team of Acceleration of Poverty Alleviation are formulating poverty alleviation policy and program, doing synergy by synchronization, harmonization, and integration of poverty alleviation program in ministry or institution (Hidayat, 2017). Considering, the community has a specific local order and can become an adaptation in overcoming poverty (Harttgen \& Klasen, 2010).

Such potential is material and nonmaterial that is useful as a source of community life needs. As the process of empowerment carried out through the movement of reading, write, calculate functional literacy programs can provide access, participation, control and a great benefit for women picking coffee workers to be with men into communities planners. Literacy programs also encourage a significant increase in power by relating to the fulfilment of the necessities of life. Findings gained that there is a local potential that can be useful and developed for the empowerment of female coffee-picking labourers through functional literacy programs, such as the access of women's coffee-picking labourers, the participation of female coffee workers, Coffee-picking workers ' control, and the benefit of the Fugsional literacy program.

Women picking coffee workers are the main local resource managers and have restricted access by the culture of partiarkhi. However, the functional literacy program can give the female movement room of coffee picking labourers to independently obtain information and access economic resources on its behalf (Eisemon, 2014). In this case, it requires a material that is capable of raising the critical awareness of female labour women who are more functional in analyzing various lives. The participation of women picking coffee workers. The learning stimuli given through the material may increase the participation of female coffee quotation unions. It was demonstrated that the involvement of female coffee picking labourers together with the tutor designed appropriate learning needs control women's picking coffee workers.

The functional literacy Program provides a variety of insight and knowledge that women are required to pick a coffee. The increase in the empowerment of female coffee quotes is demonstrated by the ability to perform controls related to their life. Where the program has provided a women's room for the female movement of coffee picking sovereign for the planning, implementation, and evaluation of the learning program independently without relying on others.

Benefits of functional literacy programs. The existence of a functional literacy program that has provided a basis for gaining knowledge has opened up women's space to engage in various activities at the family, community and country level. It was said by (Suharto, 2015) that empowerment is the giving of power to the weak. The critical awareness conducted through literacy programs as a form of enhancement of women's empowerment is done to avoid suppression due to the inability of women to analyze the source of everyday life. The empowerment of female coffee picking labours is done through the learning process of literacy which is packed in basic competency standard and consists of dimensions of attitude, knowledge and skills.

The dimension of attitude expects an increase in behaviour and ethics that reflects the believer's attitude and is responsible for interacting with the family, society and nature in everyday life. While women are often able to ignore or minimize gender inequality in such workplaces, largely explaining how it is reproduced, this was not the case for the harassing work environments described by many of our interviewees (McLaughlin, et al., 2017). Literacy Education expects a change in attitudes through materials developed following religious norms and social norms so that citizens learn to interact following the prevailing norms in society.

The dimension of knowledge contains the standard in mastering factual knowledge about how to communicate through Indonesian languange and counting to do daily activities in family life and community. Given the lack of language skills, the women of coffee picking workers ex- 
perienced obstacles to interact with others (McLaughlin et al., 2017). Therefore, the material is packaged in a form of reading, writing and counting capabilities so that it can be enabled in daily life and accordance with local potentials. The dimension of skill, implemented for women to pick up coffee can use Indonesian language and counting skills to perform daily activities in family life and community. The ability of female lack labour quotes coffee is evident from the skill of speaking and hearing a variety of information that is well received and correct.

The results of the study appear that in the implementation of functional literacy programs There is an effort to increase the empowerment of female coffee picking labourers adequate to increase knowledge in self-analysis and improve the level of life. There is a considerable potential of local resources to be developed in the learning process to be a strong point in the program to run sustainably and continuously. Equality in access and achievement of education qualifications is required to realize women picking coffee workers into agents of change in families, communities and countries development programs. The program is developmental a development empowerment program aimed at empowering potential in overcoming the problems of shared life they are facing (Ariefianto, 2019).

The involvement of outsiders from government, non-government organizations, private institutions and funding agencies is urgently needed to encourage community participation in community development (Hidayat \& Syahid, 2019). The female literacy rate of coffee quotes is an important key to increasing family resilience. The existence of functional literacy programs that are developed following local context can improve access, participation and control, as well as the benefits of the program for female coffee quotation workers. Program development, designed as a self-reliance read, write and Count competency amplifier.

Saugi and Sumarno (2015) says that women's access can increase the ability to enter into sectors in obtaining information, employment and education as well as with men. The empowerment of female labour women demonstrated the ability to acquire strategic positions in the company than ever before. Women picking coffee workers can perform wages control following the results of the work. The income gained is greater than before knowing the characters. The inability of women to recognize characters is utilized by local elites to provide wages that do not match the results of the work. In this case,
(Hadiyanti, 2008) explained that the process of community empowerment is a point of decline to establish the community to improve its level of life by using and accessing local resources as best as possible.

The existence of a literacy program contributes considerable contribution to the life of women's coffee picking labourers in Harjomulyo village. Increased knowledge gained from the introduction of characters and numbers to be enabled in analyzing various things related to daily life. As said by (Hartatik, 2019) that the advent of the education of functional literacy focuses more on the improvement of reading, writing, and counting capabilities that fit the needs of life and can enable the character in the access to Sources of life. The functional literacy Program aimed at women picking coffee workers will better answer gender's practical and strategic needs to be able to recognize the potential surrounding it. This condition makes it possible to manifest women with powerful coffee picking and competitiveness. Considering women are helpless because of the narrow space of the motion to develop potential. As (Tjiptaningsih, 2017), a powerful woman needs to be created an atmosphere that can develop the potential.

The design of literacy programs that are designed according to the local context will help women to pick up the coffee workers to recognize the local potentials that exist around it. Where the local potential is a social security net that can be a strategy adaptation of women's coffee quotation labour in overcoming poverty. (Suharto, 2015) said that to strengthen the knowledge of women required a common movement capable of cultivating all the abilities and beliefs of women to support self-reliance.

The creation of a learning Group in Literacy Education Program is a great strength for women to further develop knowledge in utilizing and developing local potential around. Tutors with citizens learning (read: women picking coffee workers) must have the ability to find local potential that can be utilized as teaching materials development. From the results of interviews and observations found a local potential that can be utilized and developed in functional literacy programs to improve the empowerment of women including natural resources, socio-cultural, economics.

Natural resources: There are natural resources in the form of coffee plants can be the learning sources contained in the form of material. Coffee plants have many benefits that can be developed as a living necessity. In addition to the 
famous coffee beans benefits, coffee waste can be utilized as soap, masks, fodder and compost. In literacy programs, It is packaged in a material developed in the form of theory and practice.

Socio-cultural: there is a variety of cultures in the life of women picking coffee workers in the form of religious, social, and economic norms. In this case, the norm can be a rule in running a literacy program. The norm that has been instittualizing can be a learning medium that has the potential to realize the ongoing learning program. In this case, the norm can be utilized and developed as a study contract. The order of community that has been institutionalized has been found and useful as a learning group. The order is a religious institution (Sarowa'an): The form of a female association of coffee-picking labourers to call for the Quran verse that takes place every Wednesday afternoon. In this activity, various religious activities have been eternally held.

Economics: In economics, women picking coffee workers have local wisdom as a social safety net to overcome poverty. The research findings describe the presence of a pet Gado system that serves as a family investment. Also, there is a system of Buthok which is a rule system in overcoming the difficulty in meeting the family economy.

On the other hand, there is a local potential in the form of social, economic, culture can be a concern for the formulation of functional literacy programs in the form of materials and form a group of learning in the community. The attention, more learning that fits the practical needs and strategic gender in women, coffee picking labourers, so that it has a critical awareness in understanding and adapting themselves in addressing the problems that Experienced. Can read opportunities related to the source of life needs.

The education of functional literacy is one of the transformative critical movements that can change the female mindset of coffee picking labourers to make a better life change. Utilization of local potentials in the program of functional literacy can realize the social change in the form of justice towards the female coffee picking workers. Paulo Freire is known for his vision of education for transformation and his articulation of the principles and practices of popular education. This is in line with the thought of (Freire, 2010) that the critical awareness that is constructed in the education of functional literacy seeks to make people aware of inequality in social conditions and aware of the elements, potentials and components In his ward.

The critical awareness efforts through lite- racy programmes are done to women picking coffee workers to be able to find, utilize and develop all potential existing to be developed into an effort to improve the quality of life. Understanding women's quotation of coffee that is built through strengthening the competency of lack can give an understanding of the gaps that occur in the reality of life. The hope of the woman becomes conscious and becomes resurrected to become a dignified man over herself. Reinforced by the findings of (Laksono et al., 2018) explains that functional literacy programs are a blessing in life for passionate and strong-willed.

Women have a conscious awareness of their rights and obligations and can work according to its compensatory, without cultural denial. As stated by (Indrianti, et al., 2019) that the objective of the education program of functional literacy is to pursue a critical awareness, so it can customize themselves in addressing the problems of life and build a community to make changes. Also (Raharjo \& Suminar, 2016) states that, through a local potential-based functional literacy program, you can provide understanding and self-adjustment to the women of coffee picking workers in addressing life issues and encouraging them to do life changes for the better.

Learning together has the potential to honor the perspectives of local communities and different cultural perspectives, and to entail an exploration of the inherent diversity and structural equity issues. omen's work as socially necessary and of economic value and its extent and variety were among the early themes in gender sensitive and feminist (McLaughlin et al., 2017). This means that the education of functional literacy based on local potentials is a chosen program to seek critical education. The pursue transformative changes in women's coffee picking workers aware to understand and make adjustments in overcoming life's problems.

The findings of this research are also similar to that of the Kinderveter (Zakiyah, 2010) that the empowerment of women can be realized through education that the women of coffee quotation workers to the potential that has been encouraged To improve and improve the quality of life. Somerville in (Zakiyah, 2010) states that with the key empowerment is placing citizens or communities in a position where they can choose the way they want to change. This means that the form of the empowerment of female coffee quotation workers can be given by freeing them to determine the choices.

The functional literacy Program is the process of empowerment to realize women who are 
capable of competitiveness. Empowerment is the core concept of the proposed model. The concept is shared by many disciplines such as community development, psychology, education, and economics (McLaughlin et al., 2017). Community empowerment as mentioned above is known as a process to strengthen the position of a less empowered society. So that there is a well-executed process to be able to produce empowerment goal that strengthens the community to be empowered (Kusiawati, 2017).

This framework attempts to empower the public to be assessed from 3 (three) aspects including enabling, which creates an atmosphere that allows the potential of society can thrive, empowering that strengthens the potential of societyowned through real steps involving the provision of various inputs and openings in various opportunities that will make the community increasingly empowered and protecting namely protecting and defending the interests of the weak community (Kusiawati, 2017).

The same thing conveyed by Arsawan, et al. (2017) that, the effort to empower the community can be seen from the three sides, namely the creation of the climate that enables the potential of developing society, increasing capacity by strengthening the potential or power Community owned (empowering) and protecting interests by developing a protection system for the communities that are subject to development.

\section{CONCLUSION}

Reformulated functional literacy by observing local potentials through material development to strengthen the competency of lack can increase the empowerment of female coffee quotes in the village of Harjomulyo Silo District Jember. The empowerment of female coffee picking workers includes an increase in reading, writing and counting skills that are ultimately able to obtain a decent job. The ability to understand the potential and opportunities there is a condition of women to understand the social problem that comes down to the ability to solve the problem of life that is faced. Therefore, the utilization of local potentials developed in the education of functional literacy is important.

\section{REREFENCES}

Ansori, T. R. (2018). Increasing Economic Capacity of Rural Community Through The Use Of Local Ecological Potency Based. Journal of Environmental Protection, 4(1), 89-96.
Ariefianto, L., \& Hilmi, M. I. (2019). The Contribution Nonformal Education in Tourism Development Through Empowerment and Training of Street Vendors. Journal of Nonformal Education, 5(1), 15-24. https://doi.org/10.15294/ jne.v5i1.18332

Arbarini, M., Jutmini, S., \& Joyoatmojo, S. (2018). Effect of Participatory Learning Model on Functional Literacy Education. Journal of Nonformal Education, 4(1), 13-24. https://doi. org/10.15294/jne.v4i1.13570

Arsawan, I. W. E., Kariati, N. M., \& Sukarta, I. W. (2017). Pemberdayaan Masyarakat Berbasis Community Development (Studi Ekploratorif di Kawasan Wisata Sangeh). SOSHUM: Jurnal Sosial Dan Humaniora [Journal of Social Sciences and Humanities], 6(3), 238-259.

Asfi, N., \& Wijaya, H. B. (2015). Efektivitas Pemberdayaan Masyarakat dalam Pengentasan Kemiskinan pada Program Gerdu Kempling di Kelurahan Kemijen Kota Semarang. Teknik PWK (Perencanaan Wilayah Kota), 4(2), 253-268.

Barton, D. (2017). Literacy: An introduction to the ecology of written language. New York: John Wiley \& Sons.

Darusman, Y. (2016). Kearifan Lokal Kerajinan Bordir Tasikmalaya Sebagai Ekonomi Kreatif Terbuka Untuk Modern (Studi di Kota Tasikmalaya Jawa Barat). Journal of Nonformal Education, 2(2), 108-119. https://doi.org/10.24914/jne. v2i2.6556

Eisemon, T. O. (2014). Benefiting from basic education, school quality and functional literacy in Kenya (Vol. 2). Amsterdam: Elsevier Ltd.

Falaly, E. A., \& Ilyas, I. (2016). Pengaruh Pelatihan Keterampilan Sapu Glagah Terhadap Minat Berwirausaha Pemuda Desa Gunungsari Kecamatan Pulosari. Journal of Nonformal Education, 2(2), 144-150.

Hadiyanti, P. (2008). Strategi Pemberdayaan Masyarakat Melalui Keterampilan Produktif. Perspektif Ilmu Pendidikan, 17(9), 90-99.

Harttgen, K., \& Klasen, S. (2010). A household-based Human Development Index. In Proceedings of the German Development Economics Conference (pp. 1-72).

Hartatik, S. (2019). Keberdayaan Perempuan Buruh Petik Kopi Melalui Pendidikan Keaksaraan Fungsional Berbasis Potensi Lokal di Desa Harjomulyo Kecamatan Silo Kabupaten Jember. Jember: Universitas Jember.

Herwiandini, M. (2018). Upaya Pembangunan Indonesia Untuk Mencapai Target Ketiga Millennium Development Goals (MDGs) Tentang Pemberdayaan Perempuan. Malang: Universitas Muhammadiyah Malang.

Hidayat, D. (2017). Pengelolaan Pembelajaran Berbasis Kewirausahaan Masyarakat Program Kejar Paket C. Journal of Nonformal Education, 3(1), 1-10. https://doi.org/10.15294/jne.v3i1.8727

Hidayat, D., \& Syahid, A. (2019). Local Potential Development (Local Genius) in Community 
Empowerment. Journal of Nonformal Education, 5(1), 1-14. https://doi.org/10.15294/jne. v5i1.18343

Indrianti, D. T., Khutobah, K., \& Latif, M. A. (2017). Potensi Kearifan Lokal dalam Pendidikan Keaksaraan Fungsional pada Masyarakat Perdesaan di Kabupaten Jember. Journal of Nonformal Education, 3(2), 140-148. https://doi. org/10.24914/jne.v3i2.10949

Indrianti, D. T., Ariefianto, L., \& Halimi, D. (2019). Pemberdayaan Masyarakat melalui Pengembangan Desa Wisata Organik di Kabupaten Bondowoso. Journal of Nonformal Education and Community Empowerment, 3(1), 13-18. https:// doi.org/10.15294/pls.v3i1.31001

Karwati, L., Ansori, A., \& Mulyono, D. (2018). Women Empowerment to Build Entrepreneurship. Journal of Nonformal Education, 4(2), 169-176. https://doi.org/10.15294/jne.v4i2.16005

Kusiawati, D. (2017). Pendidikan Luar Sekolah , Universitas Pendidikan Indonesia Pendidikan Luar Sekolah, Fakultas Ilmu Pendidikan, Universitas Negeri Malang. Pemberdayaan Masyarakat, 2(1), 59-72.

Laksono, B. A., Supriyono, S., \& Wahyuni, S. (2018). Perception of Illiterate Society Toward The Functional Literacy Program. Journal of Nonformal Education, 4(2), 131-140. https://doi. org/10.15294/jne.v4i2.16003

Latifa, A. (2015). Faktor-faktor Penyebab Rendahnya Partisipasi Warga Belajar dalam Program Keaksaraan Fungsional di Keluarahan Antirogo Kecamatan Sumbersari Kabupaten Jember. Retrieved from http://repository.unej.ac.id/bitstream/handle/123456789/65672/Ainul Latifah-1018104 01034.pdf?sequence $=1$

Lestari, D. P. (2016). Pola Pembelajaran Program Kecakapan Hidup (Life Skill) Menjahit Di BLK Kabupaten Pekalongan. Journal of Nonformal Education, 2(2), 120-127. https://doi. org/10.24914/pnf.v2i2.7155

Lestari, I. (2017). Relasi Negara dan Kelompok Tani (Studi tentang Upaya Pemberdayaan Kelompok Tani Sapaya di Desa Sapanang Kabupaten Bulukumba) (Doctoral dissertation, Universitas Islam Negeri Alauddin Makassar). https://doi. org/10.1016/j.sbspro.2015.04.758

McLaughlin, H., Uggen, C., \& Blackstone, A. (2017). The Economic and Career Effects of Sexual Harassment on Working Women. Gender and Society, 31(3), 333-358. https://doi. org/10.1177/0891243217704631

Pathak, P. H., Feng, X., Hu, P., \& Mohapatra, P. (2015). Visible light communication, networking, and sensing: A survey, potential and challenges. IEEE communications surveys \& tutorials, 17(4), 2047-2077.

Paulo, F. (2010). Pendidikan kaum tertindas. LP3ES.

Raharjo, T. J., Suminar, T., \& Muarifuddin, M. (2016). Peran Pusat Kegiatan Belajar Masyarakat Dalam Menanggulangi Kemiskinan Melalui Pendidikan Nonformal Di Jawa Tengah. Journal of Nonformal Education, 2(1), 21-38. https:// doi.org/10.15294/jne.v2i1.5310

Saugi, W., \& Sumarno, S. (2015). Pemberdayaan perempuan melalui pelatihan pengolahan bahan pangan lokal. Jurnal Pendidikan Dan Pemberdayaan Masyarakat, 2(2), 226-238. https:// doi.org/10.21831/jppm.v2i2.6361

Suharto, E. (2015). Membangun Masyarakat Memberdayakan Rakyat Kajian Strategis Pembangunan Kesejahteraan Sosial dan Pekerjaan Sosial. Bandung: PT Refika Aditama.

Tjiptaningsih, W. (2017). Pemberdayaan Perempuan dalam Upaya Peningkatan Ekonomi Keluarga (Studi Kasus Pada Kelompok Usaha Perempuan di Desa Sindangkempeng Kecamatan Greged Kabupaten Cirebon). Reformasi : Jurnal Ilmiah Administrasi, 1(2), 28-35. https://doi. org/10.1017/CBO9781107415324.004

Wynn, A. T. (2020). Pathways toward Change: Ideologies and Gender Equality in a Silicon Valley Technology Company. Gender and Society, 34(1), 106-130. https://doi. org/10.1177/0891243219876271

Zakiyah. (2010). Pemberdayaan Perempuan Oleh Lajnah Wanita dan Putri Al-Irsyad Surabaya. Jurnal Analisa, 17(01), 37-56.

Zhou, M. (2017). Motherhood, Employment, and the Dynamics of Women's Gender Attitudes. Gender and Society, 31(6), 751-776. https://doi. org/10.1177/0891243217732320 